\title{
Infrared thermography evaluation from the back region of healthy horses in controlled temperature room
}

\author{
Avaliação termográfica da região de coluna de cavalos saudáveis em sala \\ com temperatura controlada
}

\author{
Mariana Pavelski ${ }^{\mathrm{I}}$ Mardjory da Silva Basten ${ }^{\mathrm{II}}$ \\ Eduarda Busato ${ }^{\text {II }}$ Peterson Triches Dornbusch ${ }^{\text {III }}$
}

\begin{abstract}
The infrared thermography is a diagnostic imaging tool, which measures the surface temperature of an object through its heat emission. It is a non-invasive method, painless, with no involvement of radiation. Horses have elevated incidence of back injuries which causes decrease in their performance. A rapid and accurate diagnostic is essential to start the treatment. The aim of this paper was to establish the ideal time to the animal stay e inside a controlled room to balance their temperature and in the second time verify the thermographic temperature of specific back regions. It was studied fifteen healthy horses, being performed thermography of thoracic, lumbar and pelvic regions in four different times. There was a significant difference between the thermography performed outside and inside of the controlled temperature room. It was concluded that the ideal time to the horse stay into the controlled temperature room was thirty minutes and the mean thermographic temperatures of back regions, were obtained and can be used as parameters to identify injuries in other horses.
\end{abstract}

Key words: diagnostic exam, thermographic temperatures, equine.

\section{RESUMO}

A termografia infravermelha é uma ferramenta de diagnóstico por imagem que afere a temperatura da superficie de um objeto por meio da emissão de calor por ele mesmo. É um método não invasivo, indolor, sem envolvimento de radiação. Cavalos têm alta incidência de lesões na região de coluna, causando diminuição em seu desempenho. Um diagnóstico rápido e preciso é essencial para iniciar o tratamento. O objetivo deste trabalho foi estabelecer o tempo de permanência ideal dos animais dentro de uma sala com temperatura controlada para o equilibrio de sua temperatura e, num segundo momento, verificar a temperatura termográfica de regiões especificas. Foram estudados quinze cavalos saudáveis, sendo realizada a termografia torácica, lombar e pélvica em quatro tempos diferentes. Houve uma diferença significativa entre a termografia realizada fora e dentro da sala de temperatura controlada. Concluiu-se que o tempo ideal de permanência do cavalo na sala de temperatura controlada foi de trinta minutos e foram obtidas as temperaturas termográficas médias de cada região, que podem ser utilizados como parâmetros para identificar lesões em outros cavalos.

Palavras-chave: exame diagnóstico, temperaturas termográficas, equinos.

\section{INTRODUCTION}

Surface temperature of the body can be measured through electromagnetic waves with infrared frequency and are captured by thermographic cameras. The variation of the colors indicates the temperatures obtained and are transformed into graphic images to be analyzed by software (TURNER, 2001). Thermography is a fast realization exam, non-invasive, painless, with no involvement of radiation or contrast substances (NUNES etal., 2007; Y-K, 2009; MOURA, 2011).

Thermal imaging was introduced to the equine industry in the 1960 s, primarily as a screening tool for racetracks and performance horses. In 1965 DELAHANTY \& GEORGI described the use of thermography as a diagnostic tool in the clinical veterinary routine. Nowadays there are many types of termographic cameras with high sensibility to detect

IPrograma de Pós-graduação em Ciências Veterinárias, Universidade Federal do Paraná (UFPR), 80035-050, Curitiba, PR, Brasil. E-mail: mari_medvet@hotmail.com. Corresponding author.

${ }^{\text {IIUFPR }} \overline{\text {, Curitiba, PR, Brasil. }}$

IIIDepartamento de Medicina Veterinária, UFPR, Curitiba, PR, Brasil. 
minimal changes in the body surface temperatures which it has been used in several medical specialties (angiology, rheumatology, plastic surgery, oncology) and also in equine veterinary medicine (PROKOSKI, 2000; MILKUSKA, 2006).

Thermography has been used and well accepted as a diagnostic tool in horses to detect lesions that are often not perceived by physical examination, injuries cause increased blood flow, increased metabolic activity and alterations in the local circulation due to the inflammation process (PUROHIT \& MCCOY, 1980; VON SCHWEINITZ, 1999; TURNER, 2001). The higher local temperatures are associated with these processes and registered by thermographic camera through increased emission of infrared waves (MERLA, 2009; MOURA, 2011).

There is a high incidence of thoracolumbar injuries in training horses, due to excessive physical effort in this region. Back pain is considered a major cause of decrease in performance and changes in gait of the horses (TURNER, 2003). Rapid and accurate diagnose of the lesion site are essential to treatment and a better prognosis for the patient (JEFFCOTT, 1975; LECLAIRE et al. 1996; FONSECA, 2005).

Many factors can affect the results of the thermographic examination as scars or skin cuts, trichotomy, dressings, wet hair, exercises prior to the exam and one of the most import factors is the environment temperature, so it is recommended to perform the exam inside controlled room temperatures (TURNER, 2007).

The aim of this paper was to establish the ideal time to the animal stay inside a controlled room to balance their temperature and in the second time verify the thermographic temperature of the specific back regions of healthy horses.

\section{MATERIAL AND METHODS}

Infrared thermography was performed in fifteen healthy horses of different races (shorthair), sex and ages. All of them underwent physical examination, rectal temperature was measured, inspection and palpation before being included in the study. The rectal temperature off all animals was measured using a digital thermometer before the thermographic exam and the environmental temperature was measured with a thermohigrometer, these data were recorded.The controlled temperature room was totally closed without interference of sunlight or other environmental external factors. The walls and ceiling were concrete and the floor was covered with rubber. The total size of the room was 105 cubic meters and the power of the air conditioner used was 30.000BTUs ${ }^{-1}$ (Carrier ${ }^{\circledR}$-Brazil). The horses were kept in stables separately and had not gone through any physical effort or brushing, 24 hours before termographic exam. The temperature of the room was prepared with air conditioner before starting the thermographic examinations and maintained in $21^{\circ} \mathrm{C}$, controlled with a thermohigrometer. The study consisted in two phases. In the first phase the horses were bring from the stables to perform the termographic exam, in 4 different times: first outside of the controlled temperature room (T0) and the other three times with the animal inside the controlled room, at 30 minutes (T30) , 60 minutes (T60) and 90 minutes after coming into the room (T90). The examiner was careful, trying not to touch the areas that should be photographed; meanwhile another helper kept holding the horse by the bridle. The regions evaluated were thoracic (Figure 1 - Ar2), lumbar (Figure 1 - Ar2) and pelvic regions (Figure 2) of these animals from both sides left and right. During the thermographic exam two people remained in the room, no temperature changes were observed when occurred the entrance of the examiners with the horse and movement of persons was not allowed until de end of the exam. The termographic temperatures obtained of the animals inside the climate room were compared with the temperature when the animal was outside of the room.

Once the optimal stay time for the heat balance of the animal's skin was determined it was initiated the second phase of the study. In this phase the horse was kept inside the controlled temperature room during the ideal time and thermography was performed in the same regions as cited in the first phase to determine the standard temperature of these parts of the body in healthy horses.

The termographic camera utilized was Flir E-40, image resolution of $160 \times 120$ pixels, thermal sensitivity of $0.07^{\circ} \mathrm{C}$, kept at 1 meter distance of the horse to obtain the image. To analyze the temperatures of each region it was evaluated all the images one by one in the Flir Systems ${ }^{\circledR}$ v.1.2 software using selected stand area of $20 \times 20$ pixels.

Statistically it was compared the difference of the temperatures between left and right side from the three regions and then compared the changes of temperature in the four different times (outside and inside the controlled temperature room), using Oneway ANOVA with Tukey $(\mathrm{P}<0,05)$ as a posttest. Finally the thermographic temperatures got the ideal stay time and calculate the mean temperature of each measured region. All data were statistically analyzed using the GraphPadPrism software v.5. 


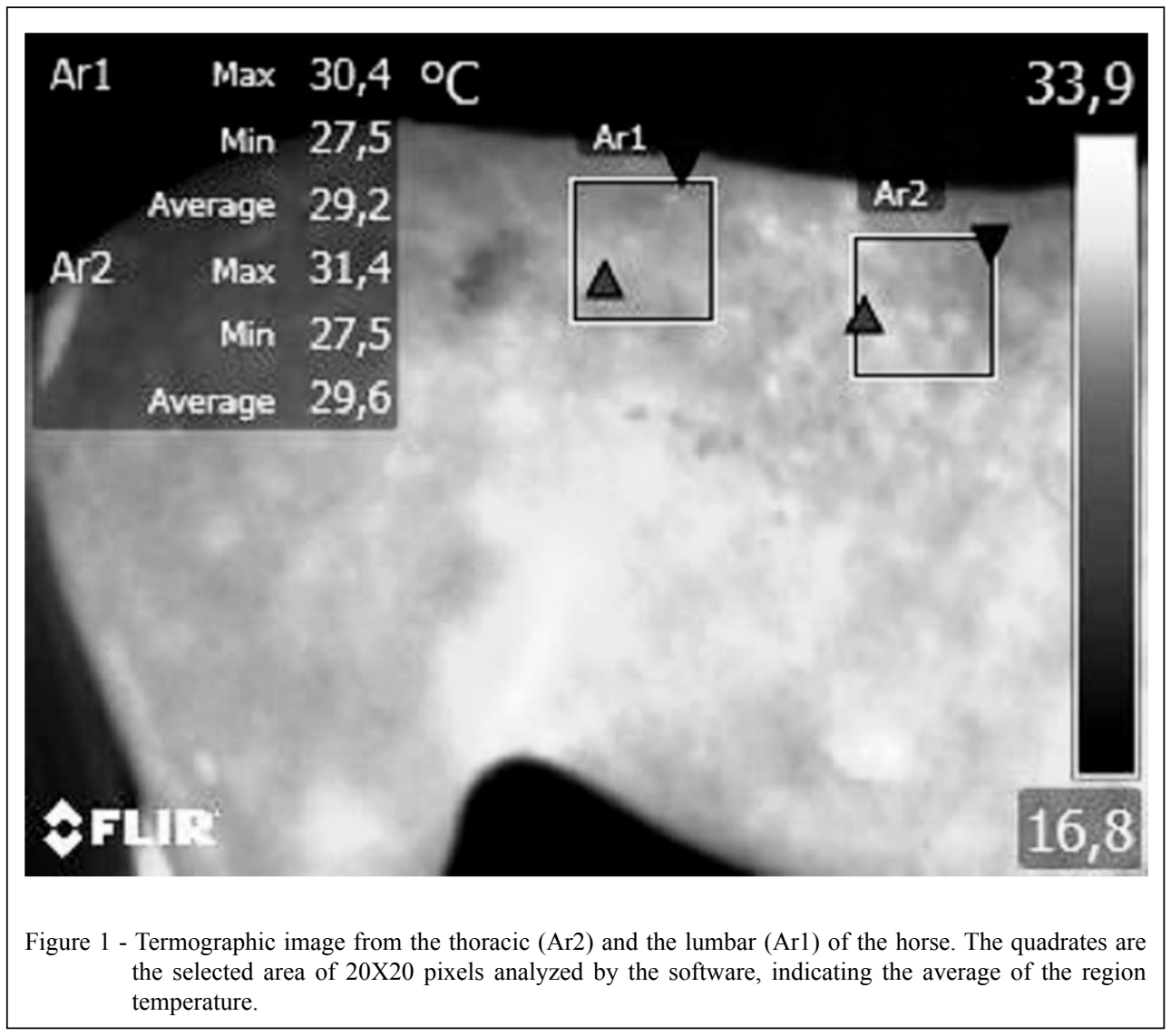

\section{RESULTS}

None of the horses had history of back injuries, in inspection and physical exam any scars, cuts, pain at palpation or other type of injury were found, and the rectal temperature of all horses were normal $\left(37\right.$ to $\left.38,5^{\circ} \mathrm{C}\right)$. The environment temperature when the experiment was conducted ranged between 14 and $23^{\circ} \mathrm{C}$.

Comparing the thermographic temperatures between right and left side of the thoracic, lumbar and pelvic regions there were no statistical difference. When compared the thermographic temperature changes associated with the different stay times (T30, T60, T90) inside the controlled temperature room there were no statistical difference. Moreover when compared the thermographic temperature outside between inside the room there was a significant statistical difference $(\mathrm{P}<0.05)$ (Table 1).

Thirty minutes inside the prepared room with a temperature of $21^{\circ} \mathrm{C}$ was enough time to balance the skin temperature of the horses and measure the temperature of the thoracic, lumbar and pelvic regions. The mean thermographic temperatures of healthy horses in controlled $21^{\circ} \mathrm{C}$ room was 29 , $5 \pm 0,2^{\circ} \mathrm{C}$ for thoracic, $29,8 \pm 0,2^{\circ} \mathrm{C}$ for lumbar and $28,2 \pm 0,2$ for the pelvic regions (Table 1).

\section{DISCUSSION}

The temperature of 21 degrees to the thermographic room was instituted based on previous human studies cited by NUNES et al. (2007) who suggest temperature between 21 to 25 Celsius degrees, BRIOSCHI et al. (2003) suggest $22^{\circ} \mathrm{C}$ and KENNEDY et al. (2009) suggested 18 to $25^{\circ} \mathrm{C}$. Also, TURNER (2007) when studied thermography in horses cited that the climate of the environment is essential and the room temperature should be under $30^{\circ} \mathrm{C}$.

It was observed a variation of the thermographic temperatures obtained when the animal is outside the controlled temperature room and this variation is almost absent inside the room, emphasizing the importance of the room with controlled temperature, the same result obtained WESTERMANN et al. (2013), which used could 


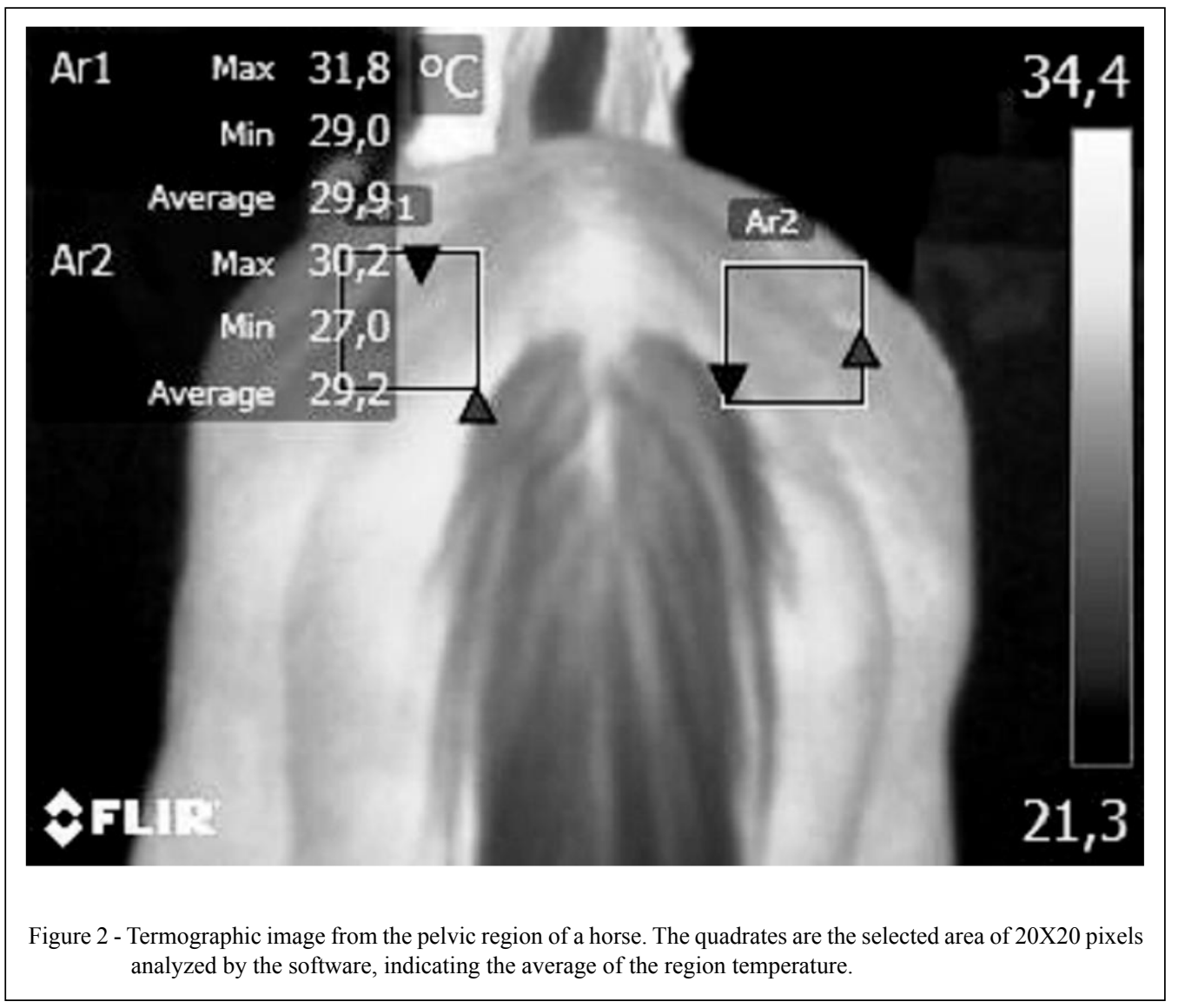

wind on and cold wind of in thermography of distal forelimbs of horses and concluded, that is essential the controlled temperature room to perform thermography, avoiding false positive or negative diagnoses. As well as it was observed in this study, MACHADO et al. (2013) when studied joints of horses, observed a positive correlation of increase or decrease in temperature of the joints according to the variation of surrounding temperature, that is, the hotter ambient temperature, the higher thermographic temperature of the measured joints.

Few studies about thermography were done with horses in controlled temperature rooms, therefore the stay time to a horse acclimatize could be questionable. This study found thirty minutes as the ideal stay time. TURNER (1991), when studied lameness quoted 10 to 20 minutes. TUNLEY \& HENDSON (2004) recommended 39 to 60 minutes to have back fully equilibrated. The point is that different of the last cited study this research prepared the $21^{\circ} \mathrm{C}$ temperature of the room before initiating the thermography exams. It allows the conclusion that the time of horse's to stay into the room depends on how the study is conducted.

Healthy horses in a controlled environment keep the temperature balanced, symmetrically. Any change in the thermal symmetry may be indicative of inflammatory processes that characterize any type of tissue injury (TURNER, 2001).

In a study conducted by FONSECA et al. (2006) about diagnostic tools for back injuries in horses showed a good relation between thermography to detect lesions and ultrasound identifying the same lesions. They concluded that thermography is a good and rapid device to be used for back diagnosis in these animals. Also TUNLEY \& HENDSON (2004) also demonstrated that thermal patter generated by horses is reproducible over intervals of up to 1 week with a confidence limit of $90 \%$.

This study presented the mean temperatures from the back, loin and croup of healthy horses; which can be very useful for equine clinicians, since horses with suspect lesions in back regions are in the same environment circumstances presented in this study. 
Table 1 - Mean and standard error of the mean thermographic temperatures measured in the three regions at different times. Different letters indicate statistical difference $(\mathrm{P}<0.05)$.

\begin{tabular}{lcccc}
\hline Region $/$ Temp $^{\circ} \mathrm{C}$ & T0 & T30 & T60 & T90 \\
\hline Thoracic & $27.5 \pm 0.4^{\mathrm{a}}$ & $29.5 \pm 0.2^{\mathrm{b}}$ & $29.4 \pm 0.2^{\mathrm{b}}$ & $29.1 \pm 0.3^{\mathrm{b}}$ \\
Lumbar & $28.0 \pm 0.5^{\mathrm{a}}$ & $29.8 \pm 0.2^{\mathrm{b}}$ & $29.8 \pm 0.2^{\mathrm{b}}$ & $29.6 \pm 0.3^{\mathrm{b}}$ \\
Pelvic region & $26.6 \pm 0.4^{\mathrm{a}}$ & $28.2 \pm 0.2^{\mathrm{b}}$ & $28.3 \pm 0.2^{\mathrm{b}}$ & $28.4 \pm 0.2^{\mathrm{b}}$ \\
\hline
\end{tabular}

\section{CONCLUSION}

The horse's stay time of thirty minutes inside a controlled $21^{\circ} \mathrm{C}$ room is enough to balance the skin temperature of the back regions as conduced in this study. Left and right sides of thoracic, lumbar and pelvic regions have no difference temperatures in healthy horses.

The mean thermographic temperatures obtained under the conditions of this study are 29 , $5 \pm 0,2^{\circ} \mathrm{C}$ for thoracic, $29,8 \pm 0,2^{\circ} \mathrm{C}$ for lumbar and $28,2 \pm 0,2$ for the pelvic regions in healthy horses.

\section{ETHICS AND BIOSAFETY COMMITTEE}

Reference n.051/2010

\section{REFERENCES}

BRIOSCHI, M. et al. Dermal thermometry: new concepts. Brazilian Vascular Journal, v.2, n.2, p.151-160, 2003. Available from: <http://jornalvascularbrasileiro.com.br/03-02-02/03-02-02151/03-02-02-151.pdf>. Accessed: Jan. 10, 2014.

DELAHANTY, D.D; GEORGI, Jr. Thermography in equine medicine. Journal of American Veterinary Medicine Association, v.147, p.235-238,1965. Available from: $<$ http://www. ncbi.nlm.nih.gov/pubmed/14325456>. Accessed: Dec. 10, 2013.

FONSECA, B.P.A. et al. Thermography and ultrasonography in back pain diagnosis of equine athletes. Journal of Equine Veterinary Science, v.26, n.11, p.507-516, 2006. Available from: <http:// www.sciencedirect.com/science/article/pii/S0737080606004989>. Accessed: Dec. 12, 2013.

JEFFCOTT, L.B. The diagnosis of diseases of the horse back. Equine Veterinary Journal, v.7, n.2, p.69-78, 1975. Available from: <http:/www.ncbi.nlm.nih.gov/pubmed/124654>. Accessed: Nov. 20, 2013.

KENNEDY, D. et al. A comparative review of thermography as a breast screening technique. Integrative Cancer Terapies, v.8, n.1, p.9-16, 2009. Available from: <http://northfloridathermography. $\mathrm{com} / \mathrm{wp}$-content/uploads/review-of-thermography-as-breastscreening-technique.pdf $>$. Accessed: Nov. 20, 2013.

LECLAIRE, R. et al. Diagnostic accuracy of technologies used in low back pain assessment: thermography, triaxial dynamometry, spinoscopy, and clinical examination. Spine, v.21, p.1325 1331, 1996. Available from: <http://www.ncbi.nlm.nih.gov/ pubmed/8725924>. Accessed: Nov. 20, 2013.
MACHADO, L.F.S. et al. Standardization of thermographic examination in metacarpophalangeal and carpal joints of horses in training. Archives of Veterinary Science, v.18, n.4,p.40-45, 2013. Available from: <http://ojs.c3sl.ufpr.br/ojs-2.2.4/index.php/ veterinary/article/view/30181>. Accessed: Jan. 10, 2014.

MERLA, A. et al. Thermal imaging of cutaneous temperature modifications in runners during graded exercise. Annals of Biomedical Engeneering, v. 38, p.158-163, 2009. Available from: $<$ http://www.ncbi.nlm.nih.gov/pubmed/19798579>. Accessed: Nov. 20, 2013.

MIKULSKA, D. Contemporary applications of infrared imaging in medical diagnostics, Annales Academiae Medicae Stetinensis, v.52, p.35-39, 2006. Available from: <http://www.ncbi.nlm.nih. gov/pubmed/17131845>. Accessed: Jan. 12, 2014.

MOURA, D.J.; MAIA, A.P. Use of infrared thermography analysis of thermoregulation in the horse in training. Agricultural Engineering, v.31, n.1, p.23-32, 2011. Available from: $<$ http://www. scielo.br/pdf/eagri/v31n1/v31n1a03>. Accessed: Jan. 12, 2014.

NUNES, L.A.O. et al. Câmera termográfica nacional. Prática Hospitalar, Ano IX, n.49, p.18-21, 2007. Available from: <http:// www.praticahospitalar.com.br/>. Accessed: Dec. 10, 2013.

PROKOSKI, F. History, current status, and future of infrared identification. Institute of eletrical and eletronicsengenieers, 2000. Available from: <http://ieeexplore.ieee.org/xpl/login.js $\mathrm{p}$ ? $\mathrm{tp}=\&$ arnumber $=855245 \& \mathrm{url}=\mathrm{http} \% 3 \mathrm{~A} \% 2 \mathrm{~F} \% 2$ Fieeexplore. ieee.org\%2Fxpls\%2Fabs all.jsp\%3Farnumber\%3D855245>. Accessed: Dec. 10, 2013.

PUROHIT, R.C.; MCCOY, M.D. Thermography in the diagnosis of inflammatory processes in the horse. American Journal of Veterinary Research, v.41, p.1167-1174, 1980. Available from: $<$ http://www.ncbi.nlm.nih.gov/pubmed/7447110>. Accessed: Jan. 12, 2014

TUNLEY, B.V.; HENSON, M.D. Reliability and repeatability of thermographic examination and the normal thermographic image of the thoracolumbar region in the horse. Equine Veterinary Journal, v.36,n.4, p.306-312, 2004. Available from: <http://www. ncbi.nlm.nih.gov/pubmed/15163036>. Accessed: Jan. 10, 2014.

TURNER, T.A. Back problems in horses. In: ANNUAL CONVENTION OF THE AMERICAN ASSOCIATION OF EQUINE PRACTIONERS - AAEP, 49., 2003a, New Orleans, Lou. Proceedings... Available from: <http://www.ivis.org $>$. Accessed: Nov. 12, 2013.

TURNER, T.A. Use of thermography in equine lameness evaluation. In: NORTH AMERICAN VETERINARY CONFERENCE NAVC, 2007, Orlando, Fla. Proceedings... Available from: $<$ http:// www.ivis.org $>$. Accessed: Nov. 12, 2013. 
TURNER, T.A. Diagnostic thermography. Veterinary Clinics North American Equine Practice, v.17, p.95-113, 2001. Available from: $<$ http:// www.ncbi.nlm.nih.gov/pubmed/11488048>. Accessed: Jan. 10, 2014.

TURNER, T.A. Thermography as an aid to the clinical lameness evaluation. Veterinary Clinics North America: Equine Practice, v.7, p.311-338, 1991. Available from: <http://www.ncbi.nlm.nih. gov/pubmed/1933566>. Accessed: Nov. 12, 2014.

VON SCHWEINITZ, D.G. Thermographic diagnostics in equine back pain. Veterinary Clinics North America: Equine Practice, v.15, n.1, p.161-177, 1999. Available from: <http://webcache. googleusercontent.com/search?q=cache:Cf0KFRZA0pkJ:www. researchgate.net/profile/Dietrich_Graf_von_Schweinitz/
publication/13080649_Thermographic_diagnostics_in equine_back_pain/file/f2 faf $4 \mathrm{f} 5 \mathrm{~d} 15 \mathrm{ef0da} 3 \mathrm{c} . \overline{\mathrm{pdf}}+\& \mathrm{~cd}=1 \& \mathrm{hl}=\mathrm{pt}-$ BR\&ct $=$ clnk $>$. Accessed: Jan. 12, 2014.

WESTERMANN, S. et al. The effect of airflow on thermographically determined temperature of the distal forelimb of the horse. Equine Veterinary Journal, v.45, p.637-641, 2013. Available from: <http:// www.ncbi.nlm.nih.gov/pubmed/23294196>. Accessed: Jan. 10, 2014.

Y-K, N.G.E. A review of thermography as promising non-invasive detection modality for breast tumor. International Journal of thermal Sciences, v.48, p.849-859, 2009. Available from: <http:// www.sciencedirect.com/science/article/pii/S129007290800149X>. Accessed: Dec. 12, 2013. 